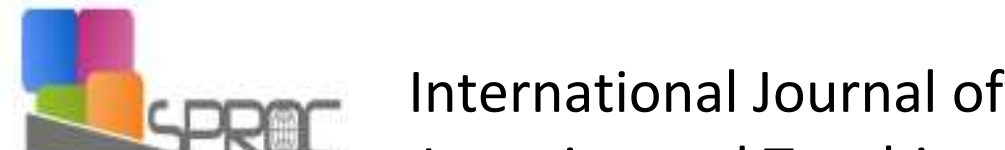 Learning and Teaching
}

Volume 10, Issue 4, (2018) 350-354

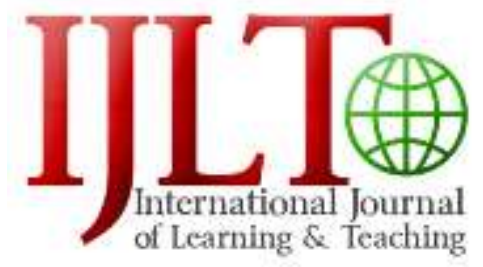

www.ij-lt.eu

\section{A pathological analysis of barriers to vocabulary learning and teaching}

Fahimeh Farjami*, English Instructor and Researcher, PiriReis University, Istanbul, Turkey

\section{Suggested Citation:}

Farjami, F. (2018). A pathological analysis of barriers to vocabulary learning and teaching. International Journal of Learning and Teaching. 10(4), 350-354.

Received from December 25, 2017; revised from May 12, 2018; accepted from September 11, 2018.

Selection and peer review under responsibility of Prof. Dr. Hafize Keser, Ankara University, Ankara, Turkey.

${ }^{\circ} 2018$ SciencePark Research, Organization \& Counseling. All rights reserved.

\begin{abstract}
Learning a foreign or second language at different levels of proficiency involves the acquisition of a great number of words. Language learners look for effective ways to increase opportunities for retaining new words in long-term memory, but forgetting is a common problem The importance of vocabulary learning also poses some challenges for teachers. They like to know in what ways instructional programmes might foster the acquisition of so many words. In this study, learners' problems in vocabulary learning are elaborated on and some guidelines are offered to ameliorate or even to remove them. It introduces language learning strategies that make vocabulary learning interesting and easy for learners. It also familiarises teachers with useful techniques and activities for presentation. A misconception analysis of teachers' and students' attitudes to vocabulary learning is carried out in terms of learning strategies, dictionary use, input, intake, output, affective variables, mnemonic devices, declarative and procedural memories.
\end{abstract}

Keywords: Vocabulary learning, forgetting, memory, mnemonic devices, input, intake, output.

\footnotetext{
* ADDRESS FOR CORRESPONDENCE: Fahimeh Farjami, English Instructor and Researcher, PiriReis University, Istanbul, Turkey.
} E-mail address: ffariami@pirireis.edu.tr / Tel.: +90 2165810050. 
Farjami, F. (2018). A pathological analysis of barriers to vocabulary learning and teaching. International Journal of Learning and Teaching. 10(4), 350-354

\section{Introduction}

According to Nation (1990), language learners themselves believe that inadequate vocabulary knowledge is the first and most common problem when they face many difficulties in both receptive and productive language use. Oxford (1990) found that 'language learners have a serious problem remembering the large amounts of vocabulary necessary to achieve fluency'. According to Rahimi (2008), students don't know which dictionaries (monolingual, bilingual or bilingualized) they should use, and when encountering new words, they mostly check the very first meaning provided in the dictionary. Lack of sufficient input and output is the other source resulting in forgetting (Brown, 2000; Celce-Marcia, 2001). Rote learning of vocabulary is one of the key factors to forgetting against which meaningful learning theory was proposed (Brown, 2000). Various factors like explicit and implicit techniques, individual and group-based activities, motivation and learning strategies are all included in the vocabulary learning process (Coady, 1997; Nation \& Newton, 1997). Regarding the learners' problems to learn vocabulary in long-term and the teachers' challenges to teach vocabulary efficiently, practical vocabulary learning strategies and influential teaching techniques of scholars are put forward in the present study.

\section{Techniques and strategies on vocabulary l1earning}

According to McCarthy and Wigglesworth (2001), extensive reading will probably be the main chance for many learners to encounter a wide range of new words. Davies and Pears (2003), Oxford and Crookall (1990), Krashen (1989) and Crow (1986) suggest that intentional learning tasks and rote memorisation should be discouraged and new vocabulary items should be presented in contexts rich enough to provide clues to meaning and that students be given multiple exposures to items they should learn. Accordingly, both the explicit and the implicit should be incorporated into the teaching and learning of vocabulary (Brown, Waring \& Donkaewbua, 2008; Eysenck, 1982; Laufer, 2005; Nation, 2001; Read, 2004). According to Lewis and Hill (1990), using pictures, real objects and synonyms, miming, defining, exemplifying and translation are the eight common techniques of teaching vocabulary. Based on Lewis (1999), attitudes, time and depth of processing are factors affecting the memory in the process of retrieving and recalling.

Oxford's (1990) taxonomy of language learning strategies contains social, memory, cognitive, metacognitive, affective and compensation groups. Gu and Johnson (1996) had two main categories of learning strategies, including metacognitive and cognitive, both of which were subcategorised as guessing, using a dictionary, note-taking, rehearsal, encoding and activating. Also, There are nine clusters of vocabulary learning strategy inventory according to Stoffer (1995), including strategies involving authentic language use, strategies used for self-motivation, strategies used to organise words, strategies used to create mental linkages, memory strategies, strategies involving creative activities, strategies involving physical action, strategies used to overcome anxiety and auditory strategies.

Nation (2004) considered the memory strategies to be vital, and Oxford (1990) considered them as 'powerful mental tools' in dealing with vocabulary learning difficulties as they make learning easier, faster, more enjoyable, more self-directed and more transferable to new situations. Johnson and Obi (1993) also found that they may help learning disabled students in the area of spelling and benefit their long-term memory of vocabulary.

Nattinger (1988) believed semantic mapping, and grouping words are very beneficial for classroom activities to increase learners' recall of words. Zaid (1995) mentioned the phases of semantic mapping as 'introducing the topic, brainstorming, categorisation, personalising the map, post-assessment synthesis'. As Craik and Lockhart (1972), Craik and Tulving (1975) and Oxford (1990) put, 'depth of processing hypothesis' occurs in vocabulary learning when the learner uses more cognitive energy in manipulating and thinking about a word, and then he is more likely to recall and use it. 
Farjami, F. (2018). A pathological analysis of barriers to vocabulary learning and teaching. International Journal of Learning and Teaching. 10(4), 350-354.

According to Johnson and Pearson (1984), spreading activation models have a facilitating effect because, in the process of associations, links of mental processing is alerted. In this sense, the related sentence is comprehended quicker than an unrelated sentence.

\section{Experiments on vocabulary teaching and learning}

Rosszell's (2007) in his study at a university in Japan investigated the effect of vocabulary teaching and learning through extensive reading. He concluded that an approach which coupled extensive reading with intensive vocabulary study represented an option that was both more viable and effective for L2 learners. What Dana (2006) found in an experiment of teaching vocabulary through the Grammar-Translation Method was that it could not lead to language acquisition and her findings supported the opinions of Thuleen (1996) and tugv Krashen (1987) that the Grammar-Translation Method did not lead to effective vocabulary acquisition and that it should be tempered with other approaches for further promotion of acquisition.

Vocabulary acquisition researchers such as Webb (2009), Schmitt (2000; 2008), Hunt and Beglar (2005), Nation (1980; 1990; 2001), Prince (1996), Siebert (1930) and Thorndike (1908) found that learning word pairs is an effective, as well as time-efficient method to acquire vocabulary knowledge. Exploring students' ability levels and guessing strategies, Schouten-van Parreren (1989) found the difficulty of weak pupils with restricted word knowledge to integrate knowledge from different sources and generalise from words already learned to new words. Also, Ahmed (1989) concluded that matured learners use strategies more and with deeper processing and greater cognitive effort. Research also indicated that patterns of strategy usage could change over time as a learner either mature or became more proficient in the target language (Nielsen, 2010).

When An (2006) selected and taught 12 vocabulary learning strategies from Schmitt's (1997), he found that keyword method, verbal repetition, studying the sound of words were mostly used, while studying a word with a pictorial representation of its meaning, grouping and writing words in their word notebooks were least used, and students with high perception managed several strategies when applying them.

In their study, Gu and Johnson (1996) concluded that selective attention, self-initiation and deliberate activation of newly learned words consistently predicted both vocabulary size and general proficiency. Other predictors of success were contextual learning, note-taking strategies and dictionary. Rasekh and Ranjbery (2003) found the positive effects of explicit meta-cognitive strategy training on vocabulary learning through a 10-week treatment.

Nemati (2009) taught the meaning of new vocabulary items by giving synonyms and mini-contexts and showed the high effect of these strategies on short-term and long-term retention. A study done in Turkey revealed that students beliefs and preferences in using vocabulary learning strategies were related, and semantic mapping technique was more effective than the traditional technique in vocabulary learning. In a study comparing the gender in terms of vocabulary learning strategy use, Gu (2003) and Catalan (2003) found that females were more willing to use learning strategies than males.

\section{Implications}

As discussed, dealing with vocabulary learning difficulties is a big concern (Oxford, 1990) and no certain strategy can be applied to vocabulary learning (Fan, 2003). According to Farjami (2001), through observation and tests, teachers can find the students' problems which are as the result of lack of knowledge or misunderstandings. Accordingly, they should provide students with affirmative instructions and also uncover false assumptions.

Conventional methods of using flash cards, notebook, bilingual and monolingual dictionaries, 'shallow' sensory processing contributing to short-term memory in vocabulary learning should be replaced with new learning strategies with 'deep' semantic processing leading to long-term memory 
(Hsiao \& Oxford, 2002). As students need greater cognitive (Chen, 2005), teachers should provide examples to teach students how to process information deeply. Understanding students' beliefs of these strategies helps teachers to design suitable materials and activities, and also managers of the language programmes, being aware of individual differences, may spend extra course hours focusing on specifically strategy training and (Carrel, 1984) on parallel concept/background knowledge development. Learners will also be more secured and self-confident as these strategies activate their background information, and they are open to new vocabularies.

\section{References}

Ahmed, M. O. (1989). Vocabulary learning strategies. London, UK: British Association for Applied Linguistics, in association with Center for Information on Language Teaching and Research.

An, S. C. (2006). A study on English vocabulary learning strategies (Unpublished master's thesis). National Chiayi University, Taiwan.

Brown, H. D. (2000). Principles of language learning and teaching (4th ed.). Addison Wesley Longman, Inc.

Brown, R. W., Waring \& Donkaewbua. (2008). Incidental vocabulary acquisition from reading,reading-whilelistening, and listening to stories. Reading in Foreign Language.

Carrel, P. L. (1984). Schema theory and ESL reading: classroom implications and applications. The Modern Language Journal, 332-343.

Catalan, J. (2003). Sex differences in L2 vocabulary learning strategies. International Journal of Applied Linguistics, 54-77.

Celce-Marcia, M. (2001). Teaching English as a second or foreign language. Boston, MA: Heinel \& Heinel Publishers, a Division of Wadsworth, Inc.

Chen, Y. (2005). Barriers to acquiring listening strategies for EFL learners and their pedagogical implication.

Coady, J. (1997). In A. T. Coady (Ed.), L2 vocabulary acquisition through extensive reading. Cambridge, UK: Cambridge University Press.

Craik, F. \& Lockhart, R. S.(1972). Levels of processing: a framework for memory research. Journal of Verbal Learning and Verbal Behavior, 11, 671-684.

Craik, F. I. M. \& Tulving, E. (1975). Depth of processing and retention of words in episodic memory. Journal of Experimental Psychology General, 104, 268-294.

Crow, J. (1986). Receptive vocabulary acquisition for reading comprehension. Modern Language Journal, 242-250.

Dana, S. (2006). Methods and approaches in vocabulary teaching and their influence on students' acquisition. Masaryk University.

Davies, P. \& Pearse, E.(2003). Success in English teaching. Oxford. Oxford, UK: Oxford University Press.

Eysenck, M. (1982). In I. C. (Ed.), Incidental learning and orienting tasks. New York, NY: New York Academic Press.

Fan, M. Y. (2003). Frequency of use, perceived usefulness, and actual usefulness of second language vocabulary strategies: a study of Hong Kong Learners. The Modern Language Journal, 222-241.

Farjami, H. (2001, April-June). Misconception analysis: a necessary complement to foreign language teaching. FORUM, 39, 14.

Gu, Y. \& Johnson, R. K.(1996). Vocabulary learning strategies and language learning outcomes. Language Learning. Language Learning, 643-679.

$\mathrm{Gu}, \mathrm{Y}$. (2003). Vocabulary learning in a second language: Person, task, context, and strategies. TESL-EJ, 1-25.

Hsiao, T. \& Oxford, R. L.(2002). Comparing theories of language learning strategies: a confirmatory factor analysis. The Modern Language Journal, 368-383.

Rosszell, H. R. (2007). Extensive reading and extensive vocabulary study in Japanese university. Temple University.

Hunt, A. \& Beglar. (2005). A framework for developing EFL reading vocabulary Reading in a Foreign Language. Johnson, D. \& Obi, S. C.(1993). Mnemonics: Can you spell it? ERIC Document Reproduction Service No. ED. Johnson, D. D. \& Pearson. (1984). Teaching reading vocabulary (2nd ed.). New York, NY: Holt, Rinehart Winston. 
Farjami, F. (2018). A pathological analysis of barriers to vocabulary learning and teaching. International Journal of Learning and Teaching. $10(4), 350-354$.

Krashen, S. (1987). Principles and practices in second language acquisition. NewYork, NY: Prentice- Hall.

Krashen, S. (1989). We acquire vocabulary and spelling by reading: Additional evidence for the Input Hypothesis. Modern Language Journal, 440-462.

Laufer, B. (2005). In S. H. Foster-Cohen (Ed.), Focus on form in second language vocabulary learning. Amsterdam, The Netherlands: Benjamins.

Lewis, L. \& Hill, J.(1990). Practical techniques for language teaching. London, UK: Language Teaching Publications.

Lewis, M. (1999). How to study foreign languages. London, UK: Macmillan Press LTD.

McCarthy, M. \& Wigglesworth, G. (2001). Vocabulary teaching and learning special issue. Prospect Journal, 16(3).

Nation, I. (1980). Strategies for receptive vocabulary learning. Guidelines, 3, 1-23.

Nation, I. (1990). Teaching and learning vocabulary. New York, NY: Newbury House.

Nation, I. (2001). Learning vocabulary in another language. Cambridge, UK: Cambridge University Press.

Nation, I. (2004). Teaching and learning vocabulary [M] (p. 159). Beijing, China: Foreign language Teaching and Research Press.

Nation, P. \& Newton.(1997). Teaching vocabulary.

Nattinger, J. (1988). In R. C. (Ed.), Some current trends in vocabulary teaching. London, UK: Longman.

Nemati, A. (2009). Memory vocabulary learning strategies and long-term retention. Academic Journal. Retrieved October 10, 2009, from the Web.

Nielsen, B. (2010). A review of research into vocabulary learning and acquisition. Retrieved from http:// www.kushiroct.ac.jp/library/kiyo/kiyo36/Brian.pdf

Oxford, R. \& Crookall, D. (1990). Vocabulary learning: a critical analysis of techniques. TESL Canada Journal, 7, 9-30.

Oxford, R. (1990). Language learning strategies: What every teacher should know. New York, NY: Newbury House.

Prince, P. (1996). Second language vocabulary learning: The role of context versus translations as a function of proficiency. The Modern Language Journal, 80, 478-493.

Rahimi, A. (2008). Vocabulary learning can be fun. California Linguistic Notes Journals.

Rasekh, Z. E. \& Ranjbery. (2003). Meta cognitive strategy training for vocabulary learning. TESL-EJ, 7/2, 1-15.

Read, J. (2004). Research in teaching vocabulary. Annual Review of Applied Linguistics, 24, 146-161.

Schmitt, N. (1997). In V. D. N. Schmitt \& X. M. McCarthy (Eds.), Vocabulary learning strategies. Cambridge, UK: Cambridge University Press.

Schmitt, N. (2000). Vocabulary in language teaching. Cambridge, UK: Cambridge University Press.

Schmitt, N. (2008). Instructed second language vocabulary learning (p. 12). Language Teaching Research.

Schouten-van Parreren, C. (1989). Vocabulary learning through reading: which conditions should be met when presenting words in texts? AILA Review, 6, 7585.

Siebert, L. (1930). An experiment on the relative efficiency of studying French vocabulary in associated pairs versus studying French Vocabulary in Context. Journal of Educational Psychology, 297-314.

Stoffer, I. (1995). University foreign language students' choice of vocabulary learning strategies as related to individual difference Variables. AL: University of Alabama.

Thorndike, E. (1908). Memory for paired associates. Psychological Review.

Thuleen, N. (1996). The grammar-translation method. Retrieved 15 October, 2011, from http://www.nthuleen. com/papers/720report.html

Webb, S. (2009). Effects of receptive and productive learning of word pairs on vocabulary knowledge. Retrieved from October 11, 2011 from.

Zaid, M. A. (1995). Semantic mapping in communicative language teaching English teaching forum. New York, NY: Oxford University Press. 